\title{
Descending necrotizing mediastinitis and mediastinal abscesses following odontogenic infection: A case report
}

\author{
Diş enfeksiyonunu izleyen desendan nekrotizan mediastinit ve mediastinal abse
}

\author{
Sema Koç, İbrahim Aladağ, Levent Gürbüzler, Adnan Ekinci
}

Gaziosmanpasa University School of Medicine Department of Otorhinolaryngology, Tokat, Turkey

\begin{abstract}
Descending necrotising mediastinitis (DNM) is a type of mediastinitis caused by head and neck infections, which spreads to the mediastinum via the cervical fascial planes. This infection is a rarely reported but highly lethal infection. Computed tomography was used to diagnosis the disease and assess the efficacy of treatment. Delay in diagnosis and insufficient drainage of the mediastinum and deep neck infection are the main causes of mortality in DNM. We report on a case that was treated successfully, even if with a long, protracted course. J Clin Exp Invest 2012; 3(2): 287-289
\end{abstract}

Key words: Odontogenic infection, descending necrotising mediastinitis, mediastinal abscesses

\section{INTRODUCTION}

Acute mediastinitis is an infection involving the mediastinal connective tissue. The greater part of cases be caused by oesophageal perforation, or postoperative infection after sternotomy. ${ }^{1}$ One of the majority severe and often lethal forms of mediastinitis is descending necrotizing mediastinitis (DNM) which is caused by downward spread of head and neck infections (DNI). ${ }^{2}$ Descending mediastinitis is a rarely reported but highly lethal infection. ${ }^{3}$ The mortality of descending necrotizing mediastinitis is estimated at $30 \%$ to $40 \%$ (1). Delay in diagnosis and insufficient drainage of the mediastinum and deep neck infection are the main causes of mortality in DNM. ${ }^{4}$ We report on a case that was treated successfully, even if with a long, protracted course.

\section{CASE REPORT}

A 64-year-old man was referred to the authors' clinic for high temperature, dysphagia, sore throat, swelling and tenderness in the right submandibular re-

\section{ÖZET}

Desendan nekrotizan mediastinit (DNM), baş ve boyun enfeksiyonlarının servikal fasiyal planlar aracılığıyla mediastene yayılması sonucu oluşan mediastinit tipidir. Bu enfeksiyon nadir görülür ve yüksek oranda fatal seyreder. Bilgisayarlı tomografi tanı ve tedavinin izleminde sıklıkla kullanılır. Tanıda gecikme ve yeteriz tedavi mortalitenin temel nedenleridir. Bu yazıda başarılı bir şekilde tedavi edilen odontojenik kaynaklı DNM olgusu sunuldu.

Anahtar kelimeler: Odontojenik enfeksiyon, desendan nekrotizan mediastinit, mediastinal apse

gion. His initial complaints had been a right sided premolar toothache and swollen cheek. He had received treatment with penicillin for 4 days elsewhere but this treatment achieved no improvement.

On admission, blood pressure was $120 / 70 \mathrm{~mm}$ $\mathrm{Hg}$, respiration rate was $30 \mathrm{breath} / \mathrm{min}$, pulse rate was $110 \mathrm{beat} / \mathrm{min}$, and her body temperature was $38.9^{\circ} \mathrm{C}$. Laboratory investigations revealed leucocytosis with neutrophilia (his white cell count was $10.900 / \mathrm{mm}^{3}$ with $85 \%$ neutrophils), haemoglobin $10.4 \mathrm{~g} / \mathrm{dl}$, platelets $481000 / \mathrm{mm}^{3}$ and a raised C-reactive protein. Blood glucose, urea, sodium, potassium, urea, creatinine, and liver function tests were in the normal range. Physical examination showed dyspnea, orthopnea, tender and fluctuant right submandibular erythema and oedema extending down to the upper chest and decreased breath sounds on the right side of the chest. The maximal mouth opening was reduced significantly and the mouth floor was raised and swollen gingiva was found around the right mandibular molars. A temporary diagnosis of descending necrotizing mediastinitis resulting from odontogenic infection was given. Computed 
tomography (CT) scanning of the patient's neck showed extensive tissue loss in the cutaneous and subcutaneous tissues extending inferiorly from the level of oropharynx towards the thorax, and presence of air between subcutaneous tissues and deep neck planes. There were abscesses, the largest of which $1.5 \times 0.7 \mathrm{~cm}$ in size located at the level of oropharynx medial to the right parotid, anterior to retromandibular vein. Thoracic CT revealed an abscess of $8 \times 6 \mathrm{~cm}$ in size in the mediastinum inferior to the thyroid gland extending from retrosternal level to the left hemithorax. In line with mediastinitis, there was heterogeneous appearance and pathologic contrast involvement. Tracheotomy was performed under general anaesthesia. The patient underwent right anterior cervical incisions and abscess drainage. Widespread necrosis of the superficial fascia in the submandibular, cervical and mediastinal region was seen throughout the operation. Purulent material was seen to move from the facial planes to the mediastinum. Mediastinal abscess was drained with chest tube. Bacteriological results from samples obtained from the neck, pleura, mediastinum, and blood did not reveal any microorganism. Postoperative tazocin and clindamycin was administered. On hospital day seven, another cervicothoracic CT was done and an empyema of $11 \times 5.5 \mathrm{~cm}$ in size was detected in the left hemithorax. Drainage was carried out and chest tube was placed. Bacteriological result from sample obtained from the mediastinum did not reveal any microorganism.

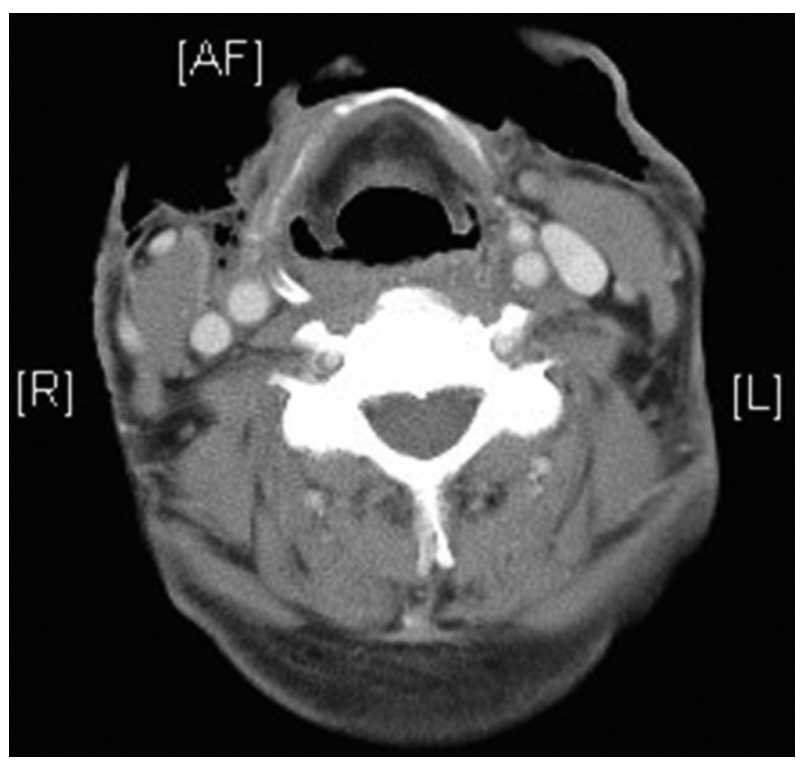

Figure 1. Preoperative CT of the neck. The neck showed extensive tissue loss in the cutaneous and subcutaneous tissues extending inferiorly from the level of oropharynx towards the thorax, and presence of air between subcutaneous tissues and deep neck planes.
In the following days, seven further surgical debridement actions were carried out and dissection was performed awaiting fresh bleeding was seen. In time necrotic tissue and exudates were greatly decreased and adequate granulation tissue was formed. Our patient made a full recovery and was discharged on day 42 of hospitalization.

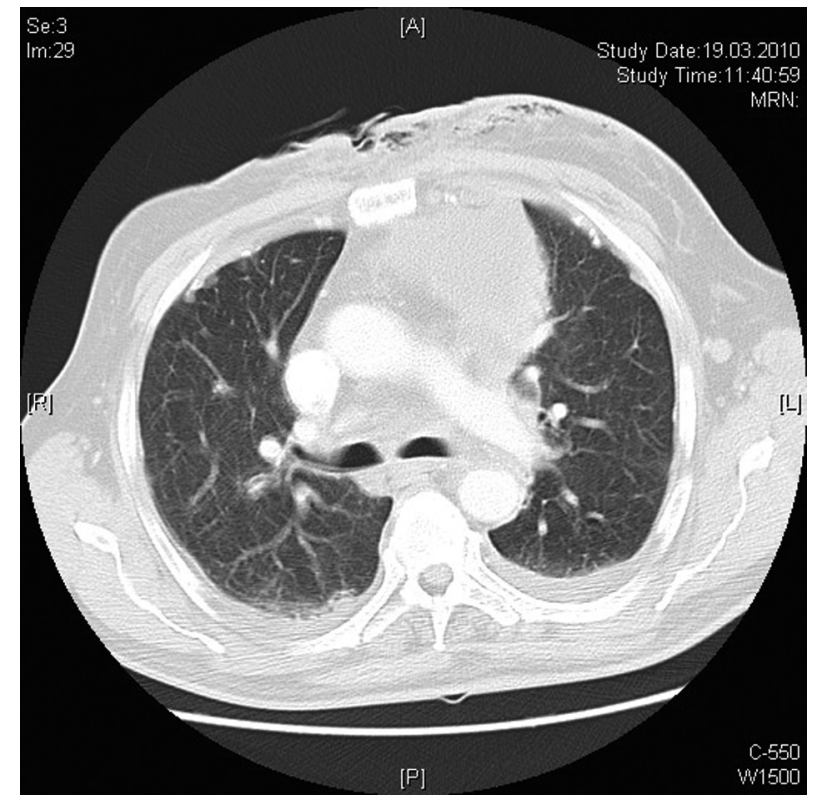

Figure 2. Preoperative CT of the chest. The abscess of $8 \times 6 \mathrm{~cm}$ in size in the mediastinum inferior to the thyroid gland extending from retrosternal level to the left hemithorax.

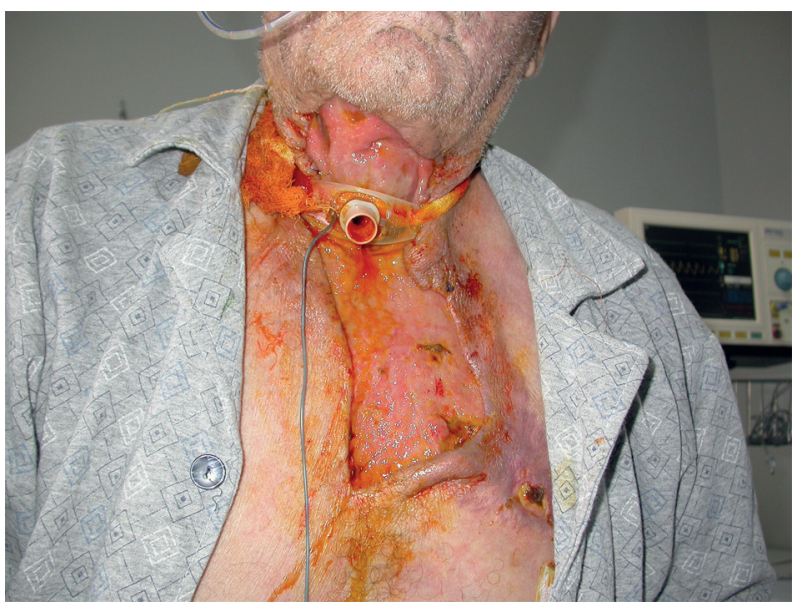

Figure 3. Descending necrotizing mediastinitis and mediastinal abscesses following odontogenic infection 


\section{DISCUSSION}

Descending necrotising mediastinitis is an unusual complication of oral and pharyngeal infections. ${ }^{5}$ Infections in the oral and pharyngeal can spread down into the mediastinum along the retrovisceral space $(71 \%$ of cases), the perivascular space $(20 \%$ of cases), and the pretracheal space ( $7 \%$ of cases), facilitated by gravity, breathing and negative intrathoracic pressure. Broadening by the pretracheal space leads to anterior mediastinal abscess. ${ }^{3,6}$

The diagnostic criteria of DNM were defined by Estrera et al. ${ }^{7}$ These include; 1 - clinical manifestations of severe oropharyngeal infection (oropharyngeal infection odontogenic or retropharyngeal abscesses, etc.); 2- exhibition of characteristic roentgenographic features of mediastinitis (radiographs of the chest will generally show gas in the tissues, air fluid levels); 3- establishment of the relation between oropharyngeal infection and the mediastinitis. Our patient met all these criteria. Bacteriologically, mediastinitis from odontogenic or pharyngeal infections is most often a polymicrobial and mixed infection involving aerobic and anaerobic organisms that play a major role. These aerobe and anaerobe organisms usually reflect the oropharyngeal flora. ${ }^{1,8}$ Because patients with DNM have frequently been treated with antibiotics for a period of time, cultures are usually negative. ${ }^{9}$ The culture results our patient were also negative. Diagnosis of descending mediastinitis is usually difficult to recognize. Physical examination and medical history can give useful information. ${ }^{3}$ The diagnosis of DNM by conventional radiological techniques may be difficult. CT is an extremely helpful tool in the diagnosis of DNM. ${ }^{9}$ The basis of treatment in patients with DNM is aggressive and sufficient surgical drainage of the cervical and mediastinal infections and systemic administration of strong, appropriate antibiotics. ${ }^{10}$ Postoperative tazocin and clindamycin was administered to our patient.

Descending necrotizing mediastinitis (DNM) secondary to descending odontogenic and pharyn- geal is rare but potentially life-threatening complication of an odontogenic and pharyngeal infections. DNM should be suspected in cases of refractory and progressively worsening odontogenic and pharyngeal infections. At present, CT scanning is an important tool for early diagnosis of DNM. Due to high mortality risk in DNM, prompt and appropriate medical management in an intensive care unit and a multi-disciplinary approach is essential.

\section{REFERENCES}

1. Pappa $H$, Jones DC. Mediastinitis from odontogenic infection. A case report. Br Dent J 2005;198(9):547-8.

2. Ridder GJ, Maier W, Kinzer S, Teszler CB, Boedeker CC, Pfeiffer J. Descending necrotizing mediastinitis: contemporary trends in etiology, diagnosis, management, and outcome. Ann Surg 2010;251(3):528-34.

3. Cai XY, Zhang WJ, Zhang ZY, Yang C, Zhou LN, Chen ZM. Cervical infection with descending mediastinitis: a review of six cases. Int J Oral Maxillofac Surg 2006;35(11):1021-5.

4. Singhal P, Kejriwal N, Lin Z, Tsutsui R, Ullal R. Optimal surgical management of descending necrotising mediastinitis: our experience and review of literature. Heart Lung Circ 2008;17(2):124-8.

5. Eren S. Descending necrotising mediastinitis. J Clin Exp Invest 2010:1(3):228-31.

6. Furst IM, Ersil P, Caminiti M. A rare complication of tooth abscess--Ludwig's angina and mediastinitis. J Can Dent Assoc 2001;67(6):324-7.

7. Estrera AS, Landay MJ, Grisham JM, Sinn DP, Platt MR. Descending necrotizing mediastinitis. Surg Gynecol Obstet 1983;157(6):545-52.

8. Levine TM, Wurster CF, Kresp YP. Mediastinitis occurring as a complication of odontogenic infections. Laryngoscope 1986;96(7):747-50.

9. De Freitas RP, Fahy CP, Brooker DS, et al. Descending necrotising mediastinitis: a safe treatment algorithm. Eur Arch Otorhinolaryngol 2007;264(2):181-7.

10. Tateya I, Fujiki N, Kurata K, Hasegawa S, Kojima H. Descending necrotizing mediastinitis following acute epiglottitis: a case report. Eur Arch Otorhinolaryngol 2003;260(3):128-30. 